\title{
Swoboda handlu międzynarodowego w prawie międzynarodo- wym, red. C. Mik, M. Jeżewski, Wydawnictwo «scriptum», Kra- ków-Warszawa 2013, ss. 394
}

Już z racji samego tematu opracowania, recenzowana książka stanowi wartość dodaną dla dorobku polskiej nauki prawa międzynarodowego. Opracowania z zakresu dość hermetycznej dziedziny prawa handlu międzynarodowego nie należą do częstych, a polska literatura przedmiotu cierpi na częsty niedosyt w tym zakresie.

Swoboda handlu zajmuje centralne miejsce w problematyce międzynarodowego prawa handlu i dotyczy mniej lub bardziej pośrednio większości innych zagadnień tego podsystemu prawa. Stąd umiejętny dobór tematów cząstkowych jest zadaniem trudnym i z góry skazanym na pewien zakres arbitralności. W recenzowanym opracowaniu znajdują się rozdziały poświęcone „klasycznym" zagadnieniom związanym z problematyką swobody handlu, jak rozdział M. Jeżewskiego dotyczący umiejscowienia omawianej zasady w systemie prawa międzynarodowego (ss. 9-42), napisany w dużej mierze pod kątem jej historycznego rozwoju. Podobnie "modelowy” charakter mają rozdziały: autorstwa Marcina Jarmoszka dotyczący swobody handlu w postanowieniach porozumień GATT i GATS, ograniczeń w handlu autorstwa Marka Jaśkowskiego, preferencji handlowych i regionalnych porozumień integracyjnych autorstwa Mateusza Iżowskiego, czego rozwinięciem są rozdziały poświęcone Unii Europejskiej i NAFT-y autorstwa odpowiednio R. Kołatka i A. Semeniuka, a także rozdział o swobodzie handlu z perspektywy Stanów Zjednoczonych autorstwa P. K. Rosiaka. Szczególną wartością książki są opracowania dotyczące obrzeży omawianej tematyki. Należą do nich rozdziały dotyczące perspektywy prawa prywatnego w odniesieniu do swobody handlu autorstwa A. Gawrysiak-Zabłockiej, warunkowania w celu zapewnienia poszanowania praw człowieka, rządów prawa i demokracji z perspektywy prawa WTO autorstwa K. Gałki oraz swobody handlu w czasie konfliktu zbrojnego autorstwa K. Masło. 
Należy zwrócić uwagę, że podjęcie się takiego opracowania było zadaniem niełatwym. Pomimo wspomnianego na początku istotnego deficytu książek z zakresu międzynarodowego prawa handlu, w polskiej literaturze istnieje już monografia P. Czubika pt. „Wolny handel towarami. Podstawy międzynarodowoprawne regionalizmu handlowego" (Zakamycze, Kraków 2002). Stanowi ona zmodyfikowaną i poszerzoną wersję wcześniej obronionego doktoratu zatytułowanego "Zasada wolnego handlu w prawie międzynarodowym” (co stwierdza Autor na s. 35). Przedmiotowa monografia odnosi się do szeregu wątków poruszanych w recenzowanej książce, nie tylko do zagadnienia regionalizmu. Nie sposób nie zauważyć, że Autorzy odnieśli się do tej pozycji raczej okazjonalnie. W rozdziale poświęconym regionalizmowi nawiązanie do niej znajduje się jedynie dwukrotnie (ss. 172, 178).

Autorzy opracowania słusznie dochodzą do wniosku, że swoboda handlu jest pewną wartością lub ideałem (s. 33, 41), który nie może być w pełni osiągnięty ponieważ pozostaje w konkurencji lub napięciu $z$ innymi domagającymi się realizacji wartościami chronionymi prawnie. Taka okoliczność nie jest dla systemu prawnego nietypowa i może nieco szkoda, że Autorzy nie pokusili się na dalsze rozważania o charakterze bardziej teoretycznoprawnym lub o analizę z pogranicza prawa i ekonomii w tym zakresie. Omawiana sytuacja została określona przez teoretyków prawa jako zawarta w normach programowych, których zadaniem jest realizacja rozmaitych celów pozostających między sobą w teoretycznej lub praktycznej konkurencji (por. L. Morawski, Wstęp do prawoznawstwa, Wydawnictwo TNOiK, Toruń 2009, ss. 57-58). Nawiązuje ona także do koncepcji „norm-zasad" (rozróżnienie rules v. principles) zaproponowanej przez R. Dworkina ${ }^{1}$. Natomiast istotną zaletą książki w zakresie rozważań teoretycznych jest powiązanie omawianej problematyki z zagadnieniem globalizacji i rosnącego znaczenia podmiotów pozapaństwowych w prawie międzynarodowym (np. ss. 13, 112).

Autorzy trafnie stwierdzają, że w gęstniejącej sieci powiązań prawnych o regionalnym lub bilateralnym charakterze, nawiązując do obrazowej koncepcji spaghetti bowl effect (s. 183), klauzula najwyższego uprzywilejowania będąca normatywną podstawą zasady swobody handlu, stała się raczej wyjątkiem niż regułą. Obecnie tworzy raczej standard do najniższego a nie najwyższego uprzywilejowania (s. 104). Do podobnego wniosku doszedł P. Czubik w cytowanej wcześniej książce pt. „Wolny handel towarami” stwierdzając, że zasada wolnego handlu jest raczej odzwierciedleniem pewnej tendencji rozwoju i bardziej zasadne wydaje się mówić o zasadzie liberalizacji handlu, która stanowi „ducha” Układu Ogólnego (s. 483).

1 R. Dworkin, Taking Rights Seriously, Duckworth, Londyn 1978, s. 14 i n. 
Wspomniane wcześniej centralne miejsce swobody handlu dla międzynarodowego prawa gospodarczego powoduje liczne implikacje dla rozmaitych innych zagadnień. Dzięki ich omówieniu opracowanie zyskuje na urozmaiceniu i staje się ciekawszą lekturą, także specjalistów z innych gałęzi prawa międzynarodowego. Jednocześnie powoduje jednak ryzyko wprowadzenia do opracowania pewnych wątków dość luźno związanych z deklarowanym w tytule tematem. Chociaż dzięki temu opracowanie zyskuje na różnorodności, traci swój monograficzny charakter. Takie podejście powoduje także zagrożenie przesadną deskrypcją, czego Autorom nie do końca udało się uniknąć. Takich opisowych, napisanych w mało problemowy sposób fragmentów w książce jest co najmniej kilka (np. wyliczenie umów z zakresu międzynarodowego obrotu handlowego i instrumentów lex mercatoria, ss. 52-66; opis historycznego rozwoju oraz porozumień tworzących prawo WTO, ss. 75-104; opis TRIPS ss. 117-136; opis Światowej Organizacji Celnej ss. 251-257; opis UNCTAD ss. 267-280). Wspomniane podejście powoduje jednocześnie, że zasadniczy, tj. poświęcony swobodzie handlu wątek miejscami zanika . Takie podejście może mieć jednak pewną zaletę, mianowicie dzięki temu opracowanie staje się merytorycznie bardziej przystępne dla szerszego grona czytelników, w mniejszym stopniu obytych z międzynarodowym prawem handlu.

Jednocześnie praca zawiera kilka bardzo dobrych rozdziałów napisanych na podstawie solidnego materiału źródłowego, cechujących się dużą klarownością i jasnością wywodu oraz problemowym przedstawieniem zawartych w nich wątków. Mogą one stanowić solidny punkt wyjścia do dalszej lektury lub badań nad omawianymi zagadnieniami. Na pewno zaliczyć do nich można rozdziały poświęcone ograniczeniom swobody handlu międzynarodowego w WTO autorstwa M. Jaśkowskiego, swobody handlu w NAF-cie autorstwa A. Semeniuka, swobody handlu i ochrony środowiska autorstwa $\succeq$. Kułagi i warunkowania celem ochrony praw człowieka, rządów prawa i demokracji autorstwa K. Gałki. Cennymi opracowaniami są także rozdziały poświęcone swobodzie handlu pisane z perspektywy prawa UE i stosunku do niej Stanów Zjednoczonych, odpowiednio autorstwa R. Kołatka i P. Kamila Rosiaka, chociaż czytelnik pozostaje z pewnym niedosytem w zakresie omówienia spraw spornych dotyczących tych podmiotów prawa międzynarodowego (odpowiednio ss. 201-207 i 244-247). W niektórych przypadkach podawane informacje mogłyby być bardziej aktualne np. w odniesieniu do cross retaliation, które zostały autoryzowane także w sprawie US-Gambling ${ }^{2}$ (s. 133).

2 United States - Measures Affecting the Cross-Border Supply of Gambling and Betting Services - Recourse to Arbitration by the United States under Article 22.6 of the DSU - Decision by the Arbitrator, 21 December 2007. 
Podsumowując należy stwierdzić, że recenzowana książka stanowi niewątpliwie istotne uzupełnienie dla polskiej literatury międzynarodowego prawa gospodarczego. Może ona z powodzeniem spełniać funkcję zaawansowanego podręcznika w dziedzinie międzynarodowego prawa handlu. Traktując ją w ten sposób, kontestowane wyżej fragmenty o charakterze ogólnym i deskryptywnym okazują się jej zaletą. Ponadto, książkę po prostu „dobrze się czyta”, chociaż niektóre jej fragmenty mogłyby zostać rozbite na punkty, co sprzyjałoby jasności wywodu (np. ss. 163-178), także czasami brakuje czytelnikowi podsumowań i konkluzji niektórych fragmentów np. w rozdziałach poświęconych TRIPS i konfliktom zbrojnym.

Piotr Szwedo*

* Dr Piotr Szwedo - Adiunkt, Zakład Prawa Międzynarodowego Publicznego, Wydział Prawa i Administracji, Uniwersytet Jagielloński. 